\title{
BRISTLELESS DWARF SPIKE- RUSH AT THE QUILL LAKES: A THIRD CANADIAN RECORD
}

STUART A. ALEXANDER, Canadian Wildlife Service, 115 Perimeter Road, Saskatoon, Saskatchewan. S7N OX4

The Bristleless Dwarf Spike-rush, Eleocharis parvula (Roem. \& Schult.) Link var. anachaeta (Torr.) Svens., ${ }^{*}$ was until now recorded in Saskatchewan and in Canada from only Goose Lake south of Tessier and, coincidentally, Goose Lake near Webb (Figure 1). ${ }^{5,3}$ Both finds were made by John $\mathrm{H}$. Hudson. The first discovery was mistakenly reported as $E$. parvula var. parvula, which, except along the Pacific Coast from California to British Columbia, is found only in eastern parts of the continent, with no inland record in Prairie Canada or the United States Great Plains west of Missouri (V.L. Harms, pers. comm.). ${ }^{5}$ This erroneous report was later corrected, and both records of Dwarf Spike-rush in Saskatchewan represent the bristle-less variety anachaeta. ${ }^{7}$ The southern Saskatchewan records of this variety represent northern outliers peripheral to its overall North American range, which extends from North Dakota and Minnesota, south to Louisiana and Texas, and west to California and Oregon. It is particularly widely distributed along the coasts of the Gulf of Mexico and the Caribbean Sea but is rarely found inland, "except perhaps in California. ${ }^{9}$
Bristleless Dwarf Spike-rush has been listed as rare and threatened in Saskatchewan, nationally rare in Canada, and not at all in the floras of either Alberta or Manitoba. ${ }^{1,2,6,8,10,11,12}$ Since Hudson's collections in 1977 and 1978, this easily overlooked species had been searched for in vain by various botanists and naturalists (V.L. Harms, pers. comm.).

Recently, however, while conducting field studies on shorebird food habits, I found stands of Bristleless Dwarf Spike-rush at three locations around the Quill Lakes: (1) extensive, dense stands along the east shore of Middle Quill (Mud) Lake; (2) a lush, dense stand in a borrow pit at the edge of the dyke in the northwest corner of Little Quill Restriction; (3) sparsely scattered, small patches along the west shore of Little Quill Lake (Figure 1). This plant probably also inhabited other basins in the vicinity of Little Quill Lake (Table 1). Voucher specimens from the first two locations are deposited in the W.P. Fraser Herbarium, University of Saskatchewan, Saskatoon (Voucher collections: 


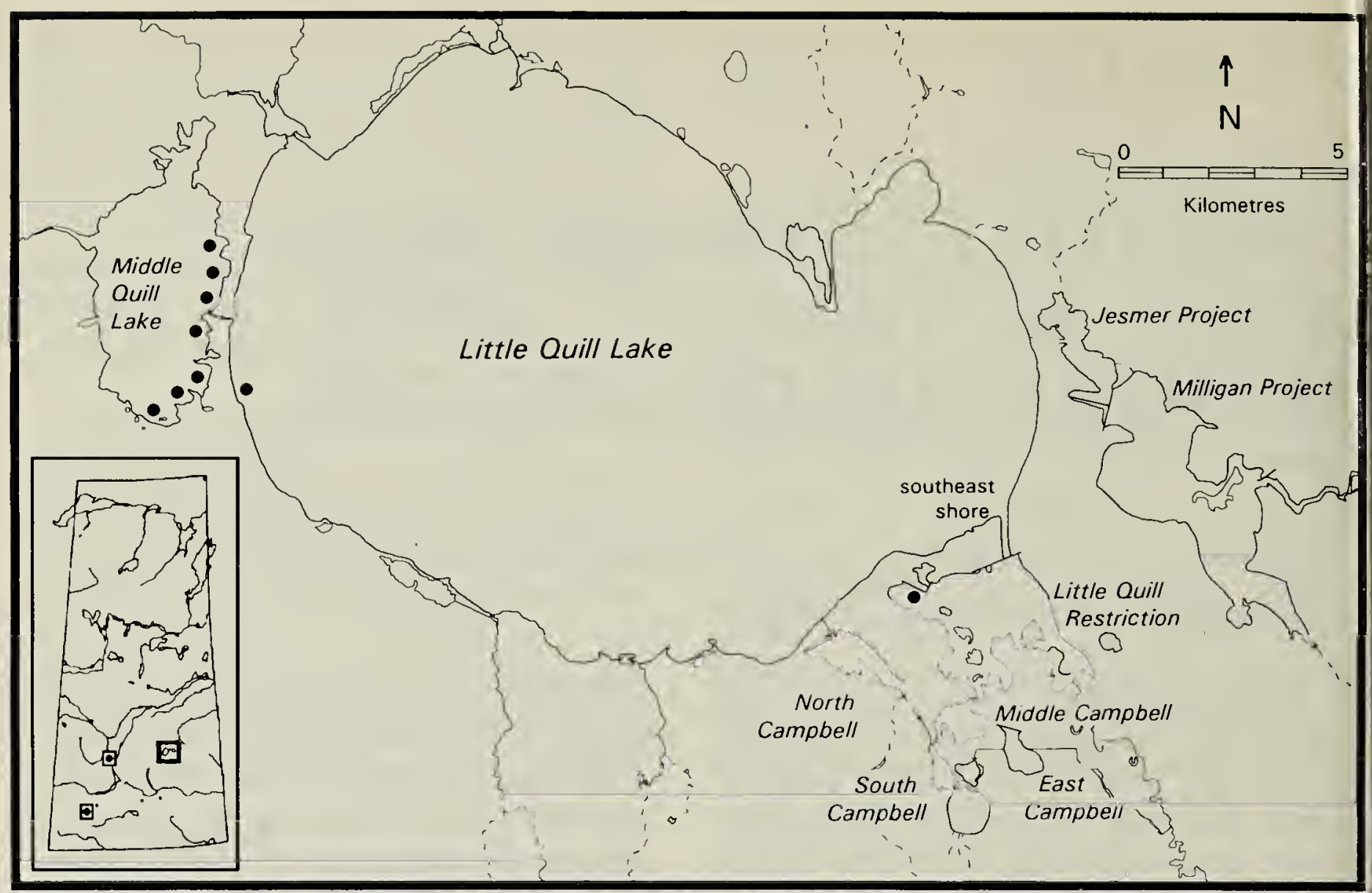

Figure 1. DISTRIBUTION OF BRISTLELESS DWARF SPIKE-RUSH IN SASKATCHEWAN AND AT THE QUILL LAKES. Previous reports are indicated by boxed dots on the inset map. Confirmed new locations are indicated by solid dots.

Stuart Alexander, s.n., 10 September 1992, SASK ACc. nos. 107678 \& 107679).

Bristleless Dwarf Spike-rush is a short plant $(1-7 \mathrm{~cm}$ tall), and may form dense, turf-like mats. It is easily mistaken for Needle Spike-rush, $E$. acicularis (L.) Roem. \& Schult., which also occurs at the Quill Lakes. But unlike the latter plant, both varieties of Dwarf Spike-rush usually bear small tubers attached to stolons, which are readily identifiable in the field without magnification. At the Quill Lakes, tubers were present at least from early July to mid-September. Other species of Eleocharis, however, also bear tubers (e.g., E. pauciflora (Lightf.) Link). Positive identification requires examination of the achene. ${ }^{9}$ Flowers bloom starting in late July and achenes mature in late August. Other characteristics for differentiating Dwarf Spike-rush from Needle Spike-rush are as follows: (1) former is annual rather than perennial, although also much tufted; (2) stylopodium (i.e., ovary-cap) is confluent with the achene summit, rather than separated from it by a constriction; (3) achene is greyishbrown and longitudinally fine-lined, rather than pearly-white and prominently ridged and cross-lined. In the variety anachaeta, perianth-bristles are absent or are three in number but greatly reduced, whereas in the variety parvula, perianth-bristles are six in number and at least as long as the achene. ${ }^{9}$

Dwarf Spike-rush resides on wet, saline mud flats associated with all types of water bodies from lakes to marshes. In July and August 1991, I 
Table 1. THE STATUS OF DWARF SPIKE-RUSH AND THE SALINITY AND pH IN BASINS AROUND LITTLE QUILL LAKE, SASKATCHEWAN

\begin{tabular}{|c|c|c|c|c|}
\hline Location (substrate) & Status & $\begin{array}{c}\text { Salinity } \\
1991\end{array}$ & $\begin{array}{l}(g / L) \\
1992\end{array}$ & $\begin{array}{c}\mathrm{pH} \\
1991\end{array}$ \\
\hline $\begin{array}{l}\text { Middle Quill Lake, east shore } \\
\text { (clayey mud) }\end{array}$ & Present, abundant & 17.0 & $4.3-5.3$ & 8.0 \\
\hline $\begin{array}{l}\text { Little Quill Lake, west shore } \\
\text { (sandy mud) }\end{array}$ & Present, sparse & 9.2 & 7.9 & 8.5 \\
\hline $\begin{array}{l}\text { Little Quill Lake, southeast } \\
\text { shore (sandy mud) }\end{array}$ & Probable, common & $7.4-10.3$ & $7.2-8.7$ & $8.5-9.2$ \\
\hline North Campbell (clayey mud) & Not checked & 5.1 & 4.5 & 8.8 \\
\hline Middle Campbell (sandy mud) & Not present & 4.1 & - & 6.7 \\
\hline East Campbell (mud) & Not present & 14.2 & - & 7.5 \\
\hline South Campbell & Not checked & 一 & - & - \\
\hline Little Quill Restriction (mud) & Probable, abundant & $4.2-6.0$ & $1.5-2.2$ & 8.6 \\
\hline $\begin{array}{l}\text { Little Quill Restriction } \\
\text { borrow pit (mud) }\end{array}$ & Present, abundant & - & - & - \\
\hline $\begin{array}{l}\text { Jesmer Project (mud with } \\
\text { plant debris) }\end{array}$ & Not present & 4.8 & - & 7.9 \\
\hline Milligan Project (mud) & Not checked & 3.5 & - & 8.2 \\
\hline
\end{tabular}

collected water samples from basins around Little Quill Lake and had them analyzed for conductivity, ionic composition (i.e., salinity), and $\mathrm{pH}$ at the University of Saskatchewan Soil Testing Laboratory. In 1992, I measured conductivity with a YSI handheld conductivity meter, and converted it to salinity using the relation between salinity and conductivity in the 1991 data (linear regression: $\log _{10}[$ Salinity $\mathrm{mg} / \mathrm{L}]=1.258$ $\log _{10}\left[\right.$ Conductivity $\mathrm{mS} / \mathrm{cm}$ at $\left.25^{\circ} \mathrm{C}\right]+$ $\left.2.843 ; r^{2}=0.99, n=15\right)$. The basins in which Bristleless Dwart Spike-rush grew were mostly hyposaline (ionic salinity of $3-20 \mathrm{~g} / \mathrm{L})^{4}$ and somewhat alkaline (Table 1).

Although not considered a submergent plant, much of the Dwarf Spike-rush at Middle Quill Lake in 1992 grew in water at least as deep as $0.5 \mathrm{~m}$, particularly in July and early August. Water levels fluctuate considerably from year to year, and were relatively high in 1992 . The submerged plants tended to be taller than exposed plants, but only the latter flowered. Submerged plants that became exposed as water levels at Middle Quill Lake dropped over the season also flowered. I noted a similar tuber-bearing species of Eleocharis submerged in the southwestern end of Little Quill Restriction (Figure 1), but water levels were high in 1992 and I could not find any specimens that were on exposed flats (except in the borrow pit, which is linked to Little Quill Restriction by a heavily vegetated marsh, and may best be considered distinct). These plants were probably also Bristleless Dwarf Spike-rush. In August and September, large quantities of submerged Spike-rush were uprooted by ducks feeding on Sago Pondweed (Potamogeton pectinatus L.) in both Little Quill Restriction and Middle Quill Lake.

In my studies on shorebird food habits at the Quill Lakes, I have found that 
Spike-rush seeds are taken by Longbilled Dowitchers (Limnodromus scolopaceus) and Stilt Sandpipers (Calidris himantopus), and that the tubers from Dwarf Spike-rush are taken by Hudsonian Godwits although both items rarely and in very small quantities. In general, shorebirds ingest seeds either incidentally or as grit, and eventually regurgitate the seeds along with other indigestible items. Seeds often retain viability after being thus used. It is possible that Dwarf Spike-rush, a normally marine, coastal species, owes its presence inland to migrating shorebirds and waterfowl. Tubers, on the other hand, are readily digestible packets of carbohydrate. They are so small, however, that they seem hardly worthwhile food for birds as large as godwits, unless encountered in abundance, such as at Middle Quill Lake.

In summary, Dwarf Spike-rush is a rare plant in Canada, but can be locally abundant in saline habitats. It may be more common in the Prairie Provinces than is presently known. Interested naturalists should look for a small spike-rush bearing tubers, perhaps especially in areas frequented by large numbers of shorebirds and waterfowl during spring migration.

Acknowledgements Funding for shorebird research was provided by the Canadian Wildlife Service University Research Support Fund and, through the efforts of $\mathrm{H}$. Loney Dickson, by the North American Waterfowl Management Plan. Vernon L. Harms and John $H$. Hudson confirmed the species identification and provided the variety classification. I would like to thank Vern Harms for encouraging this publication and for providing comments on the first draft, and Cheri L. Gratto-Trevor for reviewing the first draft.

1. ARGUS, G.W. and K.M. PRYER. 1990. Rare vascular plants in Canada
- our natural heritage. Canada Museum of Nature, Ottawa.

2. ARGUS, G.W. and D.J. WHITE. 1978. The rare vascular plants of Alberta. Syllogeus \#17. National Museums of Canada, Ottawa.

3. GLEASON, H.A. 1963. The new Britton and Brown illustrated flora of the northeastern United States and adjacent Canada. Volume 1. The Pteridophyta, Gymnospermae and Monocotyledoneae. Hafner Publishing Company, Inc., New York. 482 pp.

4. HAMMER, U.T. and J.M. HESELTINE. 1988. Aquatic macrophytes in saline lakes of the Canadian prairies. Hydrobiologia 158:101-116.

5. HARMS, V.L. and J.H. HUDSON. 1978. Some vascular plants new to the flora of Saskatchewan. Can. Field-Natur. 92:389-391.

6. HARMS, V.L., P.A. RYAN and J.A. HARALDSON. 1992. The rare and endangered native vascular plants of Saskatchewan. Report for Saskatchewan Natural History Society. The W.P. Fraser Herbarium, University of Saskatchewan, Saskatoon.

7. HUDSON, J.H. 1980. Plant finds from Saskatchewan in 1978 and 1979 mostly from the southwest. Blue Jay 38:141-145.

8. MAHER, R.V., G.W. ARGUS, V.L. HARMS, and J.H. HUDSON. 1979. The rare vascular plants of Saskatchewan. Syllogeus \#20. National Museums of Canada, Ottawa.

9. MASON, H.L. 1957. A flora of the marshes of California. University of California Press, Berkeley. 878 pp.

10. MOSS, E.H. 1983. Flora of Alberta, 2nd. edition (revised by J.G. Parker). University of Toronto Press, Toronto. $687 \mathrm{pp}$.

11. SCOGGAN, H.J. 1957. Flora of Manitoba. National Museum of Canada Bull. No. 140. Department of Northern Affairs and National Resources. Ottawa. 619 pp.

12. WHITE, D.J. and K.L. JOHNSON. 1980. The rare vascular plants of Manitoba. Syllogeus \#27. National Museums of Canada, Ottawa. 